\title{
Nuclear centre appeals to Moscow for help
}

Moscow. Russia's financial difficulties are adding to growing concern over the future of the Joint Institute for Nuclear Research (JINR) at Dubna near Moscow, until now one of the few islands of stability in the stormy sea of Russian science.

The institute was set up by Josef Stalin in the late 1940s to meet the scientific needs of the COMECON countries, acting as a rival to the European Laboratory for Particle Physics (CERN) in Geneva. But in recent years many of the former communist states have found it increasingly difficult to support the research centre.

The institute has already made adjustments to meet its new circumstances. Staff numbers, for example, have been reduced from 7,000 to about 3,500. And the JINR has been turning increasingly for support to Western nations - particularly Germany - which are now making substantial contributions to its research through

collaborative agreements.

But the JINR is facing major difficulties as the result of the failure of the Russian Federation, which pays almost one-third of the institute's costs, to pay the money it owes, in particular to cover heavy electricity bills estimated at 600 million rubles (US\$500,000) a month.

\section{IMAGE UNAVAILABLE FOR COPYRIGHT REASONS}

Dubna's 10 GeV Synchrophasotron, opened in 1957.

Despite its financial difficulties, JINR continues to develop its scientific programmes, although it has shifted its attention away from high-energy physics to fields

\section{Dubna benefits from 'brain drain'}

Moscow. Although suffering from a "brain drain' of scientists to the West, Dubna, the home of the Joint Institute for Nuclear Research (JINR), is itself benefiting from a similar process by attracting scientists from independent states where living and working conditions are even worse.

According to Alexander Rats, the town's deputy mayor, negotiations are taking place with scientists from the various regions in the former Soviet Union that have separated from Russia. Besides the JINR, Dubna is also the location of various enterprises specializing in aerospace and electronic technologies, and is keen to establish itself as a centre for high-technology research.

Dubna, like the rest of Russia, is no research paradise. Salaries are insufficient to meet minimal living needs, and are not even regularly paid. New instruments and equipment are difficult to obtain, and research institutes have heavy costs for electricity, as well as other costs unique to the Soviet scientific towns. But the situation is more stable than elsewhere, and thus has attractions for research scientists and their families.

At the end of November, for example, several leading specialists from the Sukhumi Physico-Technical Institute (SFTI) moved to the newly created Institute of PhysicoTechnical Problems based on the JINR site. The institute was specifically created in order to attract scientists such as those from Sukhumi, formerly one of the most beautiful Soviet resorts on the Black Sea but now heavily damaged by civil war in independent Georgia.

Similarly, more than 20 scientists have moved to Dubna from the Institute of Radioisotopic Instrument Engineering in Riga, which faced the threat of closure since its main research topic - the development of radiation detectors - has become of little interest to the now nuclear-free Latvia.

And in a separate development, the Ukrainian aerospace design bureau 'Typhoon', having previously been forbidden to have any contact with Russian aerospace enterprises - its main source of contracts - has now moved most of its scientific staff to Dubna.

The Russian government still does not differentiate between migrants by profession, and is trying to settle everyone in the Nechernozyomny region, the country's main agricultural area. Rats argues that this policy is short-sighted. "A doctor of science has no business in the Nechernozyomny region," he says. "A scientist has to be provided with conditions which he can work in. The return is quick, and the expenses are not too great. The state has a duty to solve this problem."

At present, however, Dubna is using its own resources to provide for immigrants from other countries of the former Soviet Union. Scientists are offered temporary accommodation, a plot of land and a loan for building a house. But the city authorities still face the problem of obtaining residence permits for 'foreign' scientists, a process that involves much bureaucracy, and for which the town administration has to pay a substantial fee. such as the investigation of nuclear structure, operating at lower energy levels.

Vladimir Kadyshevsky, who was appointed director of the institute in June 1992, claims that the value of the institute's work is confirmed by its continued success in attracting physicists from Western countries. It has also become an important supplier to the West of radioisotopes prepared with its accelerator.

Kadyshevsky says that the agreement between the JINR and the German Ministry of Research and Technology serves as a good model of collaboration. The distribution of the German contribution to JINR's budget is laid down in an intergovernmental agreement.

Similar collaborative agreements have been negotiated with Italy and France, and are under discussion with the United States. Such agreements have helped to preserve the stability of JINR.

Kadyshevsky also points out that, unlike many other governmental or parliamentary institutions, the JINR has actively maintained its contacts to former Soviet states. "Even the Baltic states are on the verge of coming back to Dubna," he says. "Lithuania, for example, is discussing with us the possibilities of their scientists working here."

But the main difficulty now facing the JINR is the failure of Russia to make its promised payments into the institute's budget. This has become a priority concern for the organization's scientific council, made up of prominent physicists from both East and West.

The council members have written to the Russian Prime Minister, V. Chernomyrdin, and to other leading ministers - including Boris Saltykov, the minister of science and technical policy - expressing their "deep concern" about the financial situation and thus the future of the institute.

Their letter says that, despite the difficult economic circumstances, scientists at the institute have continued to produce excellent scientific results. But it also says that the failure of the Russian Federation to fulfil its obligations to JINR "threatens not only those collaborations but also the future of the institute".

In response to such appeals, First Deputy Premier Yegor Gaydar is reported to have told Boris Fedorov, the minister of finance, to find extra resources to settle the centre's total debt. According to Saltykov, an agreement in principle has also been reached on a government decision to provide scientific centres with preferential rates for electricity.

These proposals have now been submitted by Saltykov to President Boris Yeltsin for his approval. But with the present political turmoil in Russia, it is likely to be some time before the issue is resolved. Carl Levitin 